\title{
Mitigating the isomorphic conflicts faced by EMNEs in Southern Europe: The case of Chinese subsidiaries in Spain
}

\begin{abstract}
Emerging market multinational enterprises (EMNEs) are rapidly increasing their foreign direct investment around the world and, in particular, in the countries of Southern Europe. Although, international business scholars have been quick to put the spotlight on this new phenomenon, the cultural adaptation of EMNE subsidiaries to host-country environments, especially those of Europe, has remained largely unexamined. This question acquires particular relevance owing to the considerable cultural distance between emerging and developed economies and the isomorphic conflicts that can arise at the subsidiary level. Here, we examine this situation by reporting two case studies of Chinese subsidiaries operating in Spain. Our findings suggest that guanxi - the deep-rooted system of personal relations and social connections founded on mutual interests - plays a major role in the search for legitimacy undertaken by Chinese subsidiaries located in Southern Europe. The adoption and adaptation of Chinese cultural values and practices to the local environment allow the subsidiary to align itself with the culture of the parent organization at the same time as it embeds itself in the host environment, thus resolving any isomorphic conflicts.
\end{abstract}

Keywords: EMNEs; Subsidiaries; Liability of Foreignness; Legitimacy; Cross-cultural Management; Cultural Adaptation; Expatriates.

Corresponding author. E-mail: felix.barahona@ub.edu

Received 01 February 2016 - Accepted 17 April 2016

This is an Open Access article distributed under the terms of the Creative Commons Attribution-Non-Commercial-No Derivatives License (http://creativecommons.org/licenses/by-nc-nd/4.0/), which permits non-comercial re-use and distribution, provided the original work is properly cited, and is not altered or transformed in any way. 


\section{Introduction}

The rise of emerging market multinational enterprises (EMNEs) is a recent phenomenon that is gaining in significance in the international business field. Not only are these companies, with their origins in emerging countries, able to compete effectively in their home markets, but they are also investing successfully in the most advanced economies, the birth place of many of the world's leading players. Indeed, the growth of EMNEs is clearly evidenced in terms of foreign direct investment (FDI). According to UNCTAD (2015), the share of global FDI outflows from emerging economies has increased from 5\% in 1990 to $14 \%$ in 2004 and 39\% in 2014. Moreover, an increasing number of EMNEs appear in Fortune's ranking of the world's 500 largest companies: in 200547 EMNEs were listed, in 2013 the number had risen dramatically to 132 , reaching 158 in 2015 , representing $32 \%$ of the Global 500.

Among the countries of Southern Europe, Spain was ranked 12th in the list of global FDI inflows (UNCTAD, 2015) with a total of 18,249 million euros, that is $18.68 \%$, originating from emerging economies. Indeed, Spanish FDI inward stock from emerging countries has risen dramatically by $159.90 \%$ in just six years (2007-2013). Consequently, investments in Spain from emerging economies are clearly on the upturn, with an average growth rate of $26.65 \%$, compared to just $1.57 \%$ in all other foreign countries. In this regard, Latin America is gradually being pushed aside by Asia, whose share of total stock has risen from $1.53 \%$ to $20.06 \%$ in only six years. In fact, in the latest Fortune 500, China had 92 (106 if we include Hong Kong and Taiwan) of the world's 500 largest corporations by revenue.

This rise of EMNEs has aroused considerable interest among academics, resulting in a broad range of empirical studies and theoretical works aimed at analysing their characteristics, determinants, pathways and performance (Buckley et al. 2007; Child and Rodrigues 2005; 
Cuervo-Cazurra 2007; Gammeltoft et al. 2010; Guillén and García-Canal 2009; Luo and Tung 2007; Mathews 2006; Ramamurti 2009). Against this backdrop, a number of specific questions arise concerning the Spanish context, most notably: What is the degree of penetration of EMNEs, particularly Chinese EMNEs, in Spain? How do Chinese firms interact with the Spanish host-environment in adapting to a new distant market? The aim of this paper therefore is to use micro-data to determine the extent of the Chinese presence in Spain and to adopt a qualitative approach in order to examine the cultural adaptation of Chinese subsidiaries to the host country. This latter question is of particular relevance, especially given the paucity of studies conducted to date examining issues of cultural fit and despite its obvious importance to the success of FDI. Chinese FDI has, on the other hand, been the subject of a number of studies, including analyses of how Chinese subsidiaries address their disadvantages in developed countries (Klossek et al. 2012; Si and Liefner 2014; Wong 2012), the factors that determine the decision-making autonomy of Chinese subsidiaries in Germany (Schüler-Zou et al. 2013) and the role played by Taiwanese subsidiaries and their overall performance (Chang et al. 2012; Chen et al. 2013; Chiao and Ying 2013).

To fill this gap in the literature, we present case studies of two Chinese subsidiaries operating in Spain that provide valuable information about how they resolve the isomorphic conflict (Forsgren 2013), by seeking internal and external legitimacy at the subsidiary level. Thus, the main contribution of this paper is to illustrate the way in which deep-rooted Chinese values and practices, especially guanxi, play a significant role in the subsidiaries to balance pressures from both the home- and host-environments. 
The rest of this paper is structured as follows. The next section describes the extent of the presence of Chinese EMNEs in Spain. Then, we examine the main theoretical arguments concerning the institutional and cultural features of Chinese subsidiaries. Section 4 discusses the research methods employed here. In the fifth section, we present our analyses and the results of our case studies of Chinese subsidiaries. Finally, we discuss our findings and identify both the limitations of this paper and future avenues of research.

\section{Presence of Chinese EMNEs in Spain}

Among its Asian partners, China has recently become the key player in the world economy in terms of FDI. Despite the ongoing slowdown in China, with an economy that is expected to grow at $6.3 \%$ in 2016 compared to $7.3 \%$ in 2014 (IMF 2016), the country is set to continue its investments in the most developed countries, thus playing a major role in the FDI arena. Spain is the $9^{\text {th }}$ largest destination for Chinese FDI among the EU-27 countries, behind the United Kingdom, Germany and France (Rhodium 2015). Indeed, Spain's position as a recipient of Chinese investment has grown rapidly in recent years. According to the Spanish Foreign Investment Registry (DataInvex) ${ }^{1}$, the evolution of Chinese FDI in Spain accelerated dramatically from 2008 onwards, increasing from 26 to 610 million EUR between 2010 and 2014 (see Table 1). In just a few years, China rose to second place in the rankings behind only Mexico, having occupied a distant $19^{\text {th }}$ place in 2009 . This rapid growth means that today

\footnotetext{
${ }^{1}$ DataInvex is an official database recording all FDI in Spain since 1993. To eliminate any speculative capital movements that might blur our interpretation of this FDI, flows received by entities holding foreign securities were excluded from the analysis. Additionally, investments were included only by the 'last country of origin', as this is where the last owner of the investment resides. This approach is more reliable than including the investments by the 'immediate country of origin', since this might be a mere country of transit for tax reasons. The emerging countries included in our study are Argentina, Bahrain, Brazil, Bulgaria, Chile, China, Colombia, Czech Republic, Ecuador, Egypt, Hong Kong, Hungary, India, Indonesia, Kazakhstan, Korea (South Korea), Kuwait, Latvia, Lithuania, Malaysia, Mexico, Morocco, Peru, Philippines, Poland, Qatar, Romania, Russia, Saudi Arabia, Singapore, South Africa, Thailand, Taiwan, Turkey, Ukraine, United Arab Emirates, Uruguay and Venezuela.
} 
China accounts for 5\% of Spain's total FDI inflows, when barely four years ago it represented just $0.42 \%$. In terms of stock, China is also second only to Mexico, overtaking in a very short period of time the United Arab Emirates, Brazil, Saudi Arabia, Argentina and South Korea, which had been the emerging countries that invested most heavily in Spain.

Table 1. Spain's FDI inflows from China and Hong Kong (2007-2014)

\begin{tabular}{|l|c|c|c|c|c|c|c|c|}
\hline \multicolumn{1}{|c|}{ Year } & $\mathbf{2 0 0 7}$ & $\mathbf{2 0 0 8}$ & $\mathbf{2 0 0 9}$ & $\mathbf{2 0 1 0}$ & $\mathbf{2 0 1 1}$ & $\mathbf{2 0 1 2}$ & $\mathbf{2 0 1 3}$ & $\mathbf{2 0 1 4}$ \\
\hline China (Total EUR million) & 2.16 & 1.05 & 2.85 & 26.41 & 62.16 & 141.68 & 526.54 & 610.31 \\
\hline Hong Kong (Total EUR million) & 2.61 & 0.26 & 1.12 & 25.58 & 5.22 & 40.33 & 241.16 & 245.20 \\
\hline $\begin{array}{l}\text { China and Hong Kong (Total EUR } \\
\text { million) }\end{array}$ & $\mathbf{4 . 7 8}$ & $\mathbf{1 . 3 0}$ & $\mathbf{3 . 9 7}$ & $\mathbf{5 1 . 9 9}$ & $\mathbf{6 7 . 3 8}$ & $\mathbf{1 8 2 . 0 1}$ & $\mathbf{7 6 7 . 7 0}$ & $\mathbf{8 5 5 . 5 0}$ \\
\hline $\begin{array}{l}\text { China and Hong Kong as Asian emerging } \\
\text { countries (\%) }\end{array}$ & $\mathbf{0 . 7 7}$ & $\mathbf{0 . 9 4}$ & $\mathbf{5 . 1 5}$ & $\mathbf{4 6 . 5 4}$ & $\mathbf{6 2 . 5 6}$ & $\mathbf{2 9 . 9 2}$ & $\mathbf{9 0 . 8 0}$ & $\mathbf{6 4 . 7 7}$ \\
\hline $\begin{array}{l}\text { China and Hong Kong as total emerging } \\
\text { countries (\%) }\end{array}$ & $\mathbf{0 . 2 7}$ & $\mathbf{0 . 3 0}$ & $\mathbf{0 . 1 0}$ & $\mathbf{1 2 . 3 1}$ & $\mathbf{7 . 8 6}$ & $\mathbf{1 3 . 3 7}$ & $\mathbf{3 6 . 3 3}$ & $\mathbf{2 5 . 0 9}$ \\
\hline $\begin{array}{l}\text { China and Hong Kong as total foreign } \\
\text { countries (\%) }\end{array}$ & $\mathbf{0 . 0 2}$ & $\mathbf{0 . 0 0}$ & $\mathbf{0 . 0 3}$ & $\mathbf{0 . 4 2}$ & $\mathbf{0 . 2 7}$ & $\mathbf{1 . 2 4}$ & $\mathbf{4 . 5 6}$ & $\mathbf{4 . 6 9}$ \\
\hline
\end{tabular}

Source: Spanish Foreign Investment Registry (DataInvex)

We identified 86 Chinese capital firms in Spain in 2013 in the SABI database ${ }^{2}$. These subsidiaries represent $6.14 \%$ of employees, $4.70 \%$ of operating revenue and $2.27 \%$ of assets of all the EMNEs with a direct presence in Spain (see Table 2). In terms of mean size, Chinese firms have caught up with their counterparts in other emerging Asian countries, including Korea. Therefore, among the many emerging countries included in this study, China is increasingly establishing itself as a highly relevant player in Spain. However, if we compare Chinese MNEs located in Spain with their counterparts from other developed countries, they still represent just a small fraction. This is in line with the data described above for Chinese outflows from the country. Indeed, the vast majority of Chinese

\footnotetext{
${ }^{2}$ The SABI database (Iberian Balance Sheets Analysis System) includes financial data from more than 2,000,000 Spanish companies. The firms selected in our sample had to be subsidiaries in which at least $50.01 \%$ of their capital belonged to MNEs from the emerging countries selected. Note, we do not differentiate between investments from China and Hong Kong, given that Hong Kong serves as an important bridge for Chinese firms wishing to venture overseas (Aminian et al. 2008), providing a platform for tax purposes and allowing them to avoid Chinese Government regulations (Ramasamy et al. 2012). Besides, given Hong Kong's role in roundtripping, we have sought to exclude investments from developed economies or other foreign countries.
} 
subsidiaries featured only established in Spain from 2007 onwards. Consequently, the

Chinese presence in Spain is a nascent phenomenon, particularly when compared with FDI from developed economies.

Table 2. Comparison: Chinese subsidiaries and other foreign MNE subsidiaries in Spain (2013)

\begin{tabular}{|c|c|c|c|c|c|c|c|c|}
\hline & & $\begin{array}{l}\text { Chinese } \\
\text { subsidiaries } \\
\text { (including } \\
\text { Hong Kong) }\end{array}$ & $\begin{array}{c}\text { Emerging } \\
\text { Asian } \\
\text { subsidiaries } \\
\text { (including } \\
\text { China and } \\
\text { Hong Kong) }\end{array}$ & $\begin{array}{c}\text { EMNEs } \\
\text { subsidiaries }\end{array}$ & $\begin{array}{c}\text { Total } \\
\text { foreign } \\
\text { subsidiaries }\end{array}$ & $\begin{array}{l}\text { \% Chinese } \\
\text { subsidiaries } \\
\text { as total } \\
\text { Asia }\end{array}$ & $\begin{array}{c}\% \\
\text { Chinese } \\
\text { subsidiari } \\
\text { es as total } \\
\text { EMNEs }\end{array}$ & $\begin{array}{c}\text { \% Chinese } \\
\text { subsidiaries } \\
\text { as total } \\
\text { foreign }\end{array}$ \\
\hline Companies & Absolute values & 86 & 247 & 700 & 15,906 & 34.82 & 12.29 & 0.54 \\
\hline \multirow[b]{2}{*}{ Employees } & Absolute values & 3,618 & 11,186 & 58,920 & $1,320,213$ & \multirow[b]{2}{*}{32.34} & \multirow{2}{*}{6.14} & \multirow{2}{*}{0.27} \\
\hline & Average values & 50 & 60 & 127 & 137 & & & \\
\hline \multirow{2}{*}{$\begin{array}{l}\text { Operating } \\
\text { revenue* }\end{array}$} & Absolute values & 2,911 & 8,323 & 61,988 & 481,106 & \multirow{2}{*}{34.98} & \multirow{2}{*}{4.70} & \multirow{2}{*}{0.61} \\
\hline & Average values & 37 & 41 & 119 & 42 & & & \\
\hline \multirow{2}{*}{ Total Assets* } & Absolute values & 1,795 & 5,150 & 78,974 & 785,389 & \multirow{2}{*}{34.85} & \multirow{2}{*}{2.27} & \multirow{2}{*}{0.23} \\
\hline & Average values & 23 & 25 & 140 & 65 & & & \\
\hline
\end{tabular}

*Absolute values in EUR million

Source: Based on data taken from SABI

Chinese firms operate mainly in the services sector, $77.91 \%$, compared to $19.77 \%$ in manufacturing industries ${ }^{3}$. Within the services sector, most companies operate in less knowledge-intensive activities $(83.58 \%)$ as wholesale traders of a diverse range of products (electronic, chemical and different types of industrial materials), while the remaining Chinese firms $(16.42 \%)$ operate in knowledge-intensive sectors, such as financial or technical activities (Table 3). As for those operating in the industrial sector, a high proportion of Chinese EMNEs work in medium-low-technology industries (52.94\%), such as metal products. However, a fairly large proportion operates in medium-high-technology industries (41.18\%), such as chemical or machinery and equipment manufacturing.

Table 3. Classification of Chinese subsidiaries in Spain by level of technology and knowledge intensity (2013)

\footnotetext{
${ }^{3}$ To analyse these companies at the sector level, we opted to apply Eurostat (2011) criterion. This approach leads to a classification based on different levels of technology and knowledge intensity of the vast range of economic activities. Thus, services are divided into knowledge intensive and less-knowledge intensive, and manufacturing industries comprise high technology, medium-high technology, medium-low technology and low technology.
} 


\begin{tabular}{|c|c|c|}
\hline & Companies & $\%$ \\
\hline Industries without technological classification (fishing, electricity) & 2 & 2.33 \\
\hline Manufacturing industries & 17 & 19.77 \\
\hline $\begin{array}{l}\text { Medium-high-technology (manufacture of chemicals and chemical products, machinery and } \\
\text { equipment, electrical equipment) }\end{array}$ & 7 & 41.18 \\
\hline $\begin{array}{l}\text { Medium-low-technology (manufacture of fabricated metal products, basic metals, rubber and } \\
\text { plastic products, other non-metallic mineral products, repair and installation of machinery and } \\
\text { equipment) }\end{array}$ & 9 & 52.94 \\
\hline Low-technology (manufacture of beverages) & 1 & 5.88 \\
\hline Services & 67 & 77.91 \\
\hline $\begin{array}{l}\text { Less-knowledge-intensive services (wholesale trade - except of motor vehicles and } \\
\text { motorcycles, warehousing and support activities for transportation, retail trade - except of motor } \\
\text { vehicles and motorcycles, wholesale and retail trade and repair of motor vehicles and } \\
\text { motorcycles, office administrative and other business support activities) }\end{array}$ & 56 & 83.58 \\
\hline $\begin{array}{l}\text { Knowledge-intensive services (management consultancy activities, financial service activities, } \\
\text { activities auxiliary to financial services, architectural and engineering activities, information } \\
\text { service activities, cultural activities) }\end{array}$ & 11 & 16.42 \\
\hline TOTAL & 86 & 100.00 \\
\hline
\end{tabular}

Source: Based on data taken from SABI and Eurostat

If we examine the degree of diversification of Chinese EMNEs in Spain, half the subsidiaries (51.16\%) are active in just one sector, preferring to focus their efforts on just one business and tending not to diversify ${ }^{4}$. Among diversified subsidiaries (48.84\%), 17 firms (19.77\%) have opted for a relational diversification strategy, while the remaining $29.07 \%$ have opted in favour of non-relational diversification. This latter strategy is a typical characteristic of EMNEs (Khanna and Palepu 2006; Cuervo-Cazurra 2007).

An analysis of the capital ownership of Chinese subsidiaries in Spain reveals a degree of balance between public and private equity firms. While 52 firms $(60.47 \%)$ are wholly owned by private investors, the remaining 34 companies $(39.53 \%)$ are state-owned enterprises

\footnotetext{
${ }^{4}$ In line with Hitt et al. (1997) to measure the degree of diversification we adopt the following criteria: a firm presents no diversification if it does not have a secondary NACE classification; a firm implements a relational diversification strategy if it has a secondary NACE that differs from its primary NACE at the three-digit level and which is equal at the two-digit level; finally, a firm presents non-relational diversification if its secondary NACE differs from its primary at both the two- and three-digit levels.
} 
(SOEs). In general, the Spanish subsidiaries of SOEs tend to be larger than privately owned enterprises, with a few exceptions, including Hutchison, Huawei and Lenovo.

Half the Chinese subsidiaries do not engage in any form of international commerce $(32.6 \%)$ or are involved solely in the import trade (17.4\%). This might indicate that their primary motive for investing in Spain is market-seeking (ESADE 2014, Nicolas 2014). In contrast, the other half does operate an export business (with $12.8 \%$ engaged just in exports and $37.2 \%$ in exports and imports). As such, their presence in Spain extends beyond the seeking of new market opportunities and these Chinese EMNEs consider Spain a channel for accessing adjacent markets as well as for acquiring strategic assets.

\section{Theoretical framework}

The success of EMNEs in advanced countries challenges present FDI paradigms. The traditional theories that explain the activities of MNEs, and which were originally developed using empirical evidence from advanced economies, may be insufficient to account for the experiences of EMNEs (Buckley et al. 2007; Child and Rodrigues 2005; Gaffney et al. 2014; Guillén and García-Canal 2009; Mathews 2002-2006; Ramamurti 2009). As a result, in recent years diverse EMNE-specific FDI theoretical perspectives have emerged (see Matthews 2006; Luo and Tung 2007; Luo and Rui 2009), which seek to explain the internationalization of EMNEs as a process for acquiring globally competitive resources and capabilities. These perspectives suggest that EMNEs differ from traditional multinationals in one key respect: their accelerated pace of internationalization. In order to expand more rapidly they sometimes prefer to enter developed markets first using cross-border acquisitions rather than to enter other similar developing economies (Luo and Tung 2007). By so doing, EMNEs can quickly 
acquire the strategic assets required to compete more effectively against global rivals at home and abroad, while avoiding institutional and market constraints.

Among the many emerging countries, China is the most active in outward FDI (MOFCOM various). In 2014, China and Hong Kong alone accounted for $48 \%$ of the emerging economies' FDI outflows, $41 \%$ of stock and $64 \%$ of the value of cross-border mergers and acquisitions (M\&As) (UNCTAD 2015). In contrast to the FDI from developed countries and from other emerging economies, Chinese FDI presents a number of distinctive characteristics. On the one hand, the main motivation of Chinese EMNEs is the opportunity to expand their market share in other host economies (see Luo and Tung 2007). This is confirmed by various econometric tests conducted on Chinese investment patterns (Buckley et al. 2007; Kolstad and Wiig 2012). According to Nicolas (2014), the European Union is no exception and market seeking is found to be the main motivation for Chinese investment, with strategic asset seeking being ranked second. Indeed, Chinese MNEs are especially interested in acquiring natural resources and superior managerial and marketing skills in order to improve their competitive advantage in manufactured products (Chen 2008; Cui and Jiang 2010; Deng 2009; Rui and Yip 2008; Nicholson and Salaber 2013; Wang et al. 2012).

However, the Chinese government plays a major role in its MNEs and its state-owned enterprises (SOEs) dominate the scene. Before 2004, private firms were not permitted to invest overseas and access to foreign exchange was allowed only to approved SOEs (Ramasamy et al. 2012). Thus, Chinese SOEs have been the main driver of the country's FDI, accounting for more than two thirds of total Chinese FDI worldwide (MOFCOM various; Morck et al. 2008). Given this legacy of institutional dependence, Chinese FDI projects today continue to be subject to governmental approval (Child and Rodrigues 2005) as it seeks to 
ensure that investments are made in line with its resource allocation plans and priorities and that they reinforce China's global influence (Luo et al. 2010). For this reason, the government monitors all foreign exchange outflows and all firms are required to report data to their corresponding provincial Bureau of Commerce (Hong et al. 2015). The Chinese government strongly encourages outward FDI in those sectors considered a priority and these firms receive greater backing in terms of organizational support, access to capital and other key inputs than their counterparts in sectors where FDI is not a priority (Ramasamy et al. 2012; Si and Liefner 2014).

Given the active role played by the Chinese government in the FDI processes, institutional theory (North 1990; Scott 1995) provides a good explanation of its overseas investments, highlighting the marked differences in the institutional frameworks of the emerging and developed economies. Indeed, several authors stress this perspective in seeking to understand the EMNE phenomenon (Gaffney et al. 2013; Wei et al. 2015). For example, Peng et al. (2008) argue that the institution-based view constitutes, along with the industry- and resourcebased views, the third leg of the EMNE strategy tripod. Institutions are "the humanly devised constraints that structure human interaction" (North 1990), and according to Scott (1995) they can be conceptualized as a set of three pillars (regulative, normative and cultural-cognitive) ${ }^{5}$. These three elements generate isomorphic pressures that may either encourage or constrain the behaviour of a subsidiary in a host-environment, thus affecting the firm's legitimacy in that setting (DiMaggio and Powell 1983; Scott 1995), where legitimacy refers to "actors' perceptions of the organization, as a judgment with respect to the organization, or as the

\footnotetext{
${ }^{5}$ The regulative pillar consists of formal institutions and related rule systems, such as laws and regulations as well as State-sanctioned enforcement mechanisms. The normative pillar comprises institutions, such as professional societies, that specify roles and guidelines for their members. The cultural-cognitive pillar consists of the shared social beliefs and values of a society's culture.
} 
behavioural consequences of perception and judgment, manifested in actors' actions'acceptance, endorsement, and so forth"” (Bitektine 2011). As such, firms achieve legitimacy by means of becoming isomorphic as a result of their adopting practices and structures that are institutionalized in a certain environment (Kostova et al. 2008).

According to Wong (2012) adaptation to local institutional pressures is more challenging when having to contend with normative and cognitive differences than when facing regulative differences. While regulatory features tend to be more formalized and more widely accepted as a motive for local adaptation, norms and cognitive elements require intensive cross-cultural communication as they tend to be more difficult to grasp, and local knowledge is largely tacit (Boyacigiller et al. 2004). Moreover, the governments of emerging countries may influence the inclination of EMNEs to expand abroad by placing SOEs under regulative and normative pressures to accommodate political objectives and "wave the national flag" (Deng 2009; Peng et al. 2008; Wang et al. 2012). Thus, the pressures that SOEs face are great when they have to make their location decision and may not be relevant to their local adaptation in the host country. For these reasons, it is our contention that the cultural-cognitive pillar takes on considerable importance when these Chinese subsidiaries interact to become isomorphic in the host-environment.

Given their distinctive institutional and social environments, Chinese MNEs face a considerable cultural distance when making cross-border acquisitions in Europe. The Chinese institutional environment is characterized primarily by a centralized, state-controlled, authoritarian culture (Hofstede 2001), and the importance of guanxi (the ancient system of personal relationships and social connections based on mutual interest and benefit) in business dealings (Hwang 1987; Kipnis 1997; Wang 2007; Yang, 1994). Basically, guanxi can be 
considered to comprise various elements, including renqing (similar to the owing of a 'favour'), ganqing (translated into English as 'feelings') and xinren (closely related to 'trust'), which together are considered as reflecting the quality or strength of guanxi (Chen and Chen 2004; Kipnis 1997; Wang 2007; Wang et al. 2008).

Because of the cultural distance between their respective institutional environments, Chinese companies entering the European market for the first time face what is known as a 'liability of foreignness' (Buckley and Casson 1976; Hymer 1960, Zaheer 1995), a heavy burden that is not easily shed and which may result in additional costs for those firms that are new to a foreign market. The greater the cultural distance, the greater this liability of foreignness will be. According to Zaheer and Mosakowski (1997), there is a close link between the liability of foreignness and the need of legitimacy of foreign firms in different cultural and institutional environments. By entering a host country by means of an M\&A, foreign firms seek to overcome their lack of local knowledge and these liabilities (Klossek et al. 2012).

Additionally, the subsidiaries of EMNEs in developed countries not only have to achieve external legitimacy (i.e., the acceptance of local players in the host country), but also retain internal legitimacy (i.e., the adoption of the institutionalized practices of the parent company and conformity with its cultural values) (Kostova et al. 2008). These often diametrically opposed environments can simultaneously exert isomorphic pulls on foreign subsidiaries, in what has been described as an 'isomorphic conflict' (Forsgren 2013). This seems to be especially challenging for Chinese subsidiaries as their requisites of internal legitimacy can differ substantially from those of their external legitimacy, because of the great institutional distance between China and Europe. Therefore, a balance has to be struck between the two pressures in order to achieve the right levels of external and internal legitimacy and, so, 
ensure the subsidiary's success in the host country. In this context, subsidiary managers play a key role in adapting the multinational to the new institutional environment. Specifically, they have to promote the integration of the Chinese multinational within a distant institutional environment while, at the same time, seeking to understand guanxi practices so as to maintain good relations with their multinational corporation.

Comparatively little research has been conducted to illustrate how Chinese subsidiaries struggle to adapt to their host-environment, and even less research has been devoted to examine how guanxi business practices are adapted to western business styles. Of the few existing studies, Si and Liefner (2014) introduced the concept of cognitive distance into the analysis of Chinese subsidiaries to study the knowledge gap that exists between parent and subsidiary; and, Wong (2012) analysed the difficulties faced by a Chinese SOE seeking to acquire a company in Australia due to institutional frictions and fear amongst the host population. Here, it is our contention that an exploration of the use of guanxi outside Chinese borders may help explain how a Chinese subsidiary in a developed country balances its need to manage globally (alignment of practices with parent organization culture) with its need to manage locally (conformity to institutional pressures of the host country) as it seeks to resolve issues of isomorphic conflict and achieve both internal and external legitimacy.

\section{Methods}

Given the current lack of understanding of the isomorphic conflict faced by Chinese subsidiaries in developed countries, we adopt a qualitative case study methodology to examine the cultural adaptation of Chinese subsidiaries to the host country. This is particularly apposite when seeking to further our understanding of a phenomenon employing an inductive approach, since it allows us to address more fully the complexity of the problem, 
the nature of the context and the behaviour of the agents involved and the relations between them (Gummesson 2006).

The case study includes two Chinese subsidiaries based in Spain. The selection of these two cases fulfils the criteria of theoretical sampling, given that they were chosen for their relevance and expected contribution to the objectives of the research (Eisenhardt 1989). More specifically, the criteria guiding the choice of the two subsidiaries were: (1) they had to be state-owned enterprises, since the government has considerable influence over Chinese MNEs; (2) both service and manufacturing industries had to be represented; (3) they had to be located in the same geographical area, so that they enjoyed the same opportunities for integrating within the local environment and establishing guanxi connections; and finally (4) they had to be managed by both local and expatriates managers, so that they were exposed to similar cognitive differences. Table 4 provides an overview of the two companies selected and their basic characteristics.

Table 4. Characteristics of the two subsidiaries

\begin{tabular}{|c|c|c|c|c|c|}
\hline Organisation & $\begin{array}{c}\text { Year of } \\
\text { entry into } \\
\text { Spain }\end{array}$ & Industry & Subsidiary activity & $\begin{array}{c}\text { Location in } \\
\text { Spain }\end{array}$ & Interviewees \\
\hline $\begin{array}{l}\text { China Shipping } \\
\text { Spain Agency, SL }\end{array}$ & 1999 & Service & $\begin{array}{l}\text { Public shipping agency, } \\
\text { international freight } \\
\text { forwarding and related } \\
\text { extension services, with } \\
\text { its headquarters in } \\
\text { Shanghai. }\end{array}$ & Barcelona & General Manager \\
\hline $\begin{array}{l}\text { Huayi Compressor } \\
\text { Barcelona, SL }\end{array}$ & 2012 & Manufacturing & $\begin{array}{l}\text { Designing, } \\
\text { manufacturing and } \\
\text { selling hermetic } \\
\text { compressors and } \\
\text { condensing units for the } \\
\text { light commercial } \\
\text { refrigeration market. }\end{array}$ & $\begin{array}{l}\text { Sant Quirze } \\
\text { del Vallés } \\
\text { (Barcelona) }\end{array}$ & $\begin{array}{l}\text { Human Resource } \\
\text { Manager }\end{array}$ \\
\hline
\end{tabular}

The data were collected through in-depth, personal, semi-structured interviews (conducted between April and November 2015) that lasted approximately three hours. Meetings were 
held with local managers of the Chinese subsidiaries (see Table 4). These informants were selected on the basis of their being directly involved in the integration process of the subsidiary within Spain, their close relationship with Chinese managers both in the subsidiary and the MNE, and their first-hand knowledge of the subsidiary's guanxi practices.

The interviews were structured in two blocks in accordance with a predetermined script based on a review of the literature: the objective of the first block was to obtain an overview of the firm's entry strategy and development, the difficulties encountered in integrating within the host institutional environment and the dynamics associated with their strategies and interactions with the parent office. In the second block, respondents were asked to describe the dynamics associated with the subsidiary's guanxi practices, the motives for applying them in Spain and the way in which this was achieved.

Once the data had been collected we began our analysis by processing all the information and filtering out any irrelevant content. All the interviews were recorded, transcribed and coded in order to structure the data and to make sure that they could be reassessed if inconsistencies were found. We used narrative techniques to construct the story of the Chinese subsidiaries in Spain from their arrival to the present day. Subsequently, we identified the three component elements making up guanxi (that is, renqing, ganqing and xinren) based on the conceptual framework provided by Yen et al. (2011) and Wang (2007). Any inaccuracies identified were resolved through mail exchange and direct phone calls.

These data was triangulated with information taken from complementary sources. We contrasted our results by conducting three in-depth, personal interviews with Chinese FDI experts holding positions of responsibility in local public organisms. Specifically, we met with the business intelligence director of Acció-Invest in Catalonia (Government of 
Catalonia), the city promotion advisor of Barcelona Activa for the Asian region (Barcelona City Council) and the economic manager of Casa Asia. These official organisations are responsible for attracting FDI to Spain and so they are also actively involved and have an indepth understanding of Chinese investment processes.

\section{Results}

Entry strategies: motivations and entry mode

The entry strategies of the two Chinese MNEs in Spain are similar despite the 14-year gap separating the two experiences. China Shipping entered the Spanish market in 1999 via a joint-venture with Pérez y Cía. The main purpose of this local alliance was to promote the commercial interests of China Shipping Group in Spain, whereby the local company serves as the consignee of the Chinese shipping company in the port of Barcelona. In Spain, as in many other countries, the law of maritime traffic obliges shipping companies to operate in ports through local consignees that act as mediators with port authorities, performing custom duties and being responsible for loading and unloading cargo and all commercial activity in the hostcountry. Thus, the entry of China Shipping Group into Spain was a strategic response to the barriers of entry (Dunning 1979) to the Spanish market protected as it was by the legislative requirements of maritime transit. The enterprise's motivation to enter the market fits well with what Luo and Tung (2007) refer to as seeking new market opportunities for two reasons.

First, China Shipping vertically integrates upstream activities by establishing its own consignee agencies in host-countries so as to achieve absolute control. According to the general manager of China Shipping Spain, "All the big shipping companies try to cover all activities of the value chain [fully integrated logistics, consignment and containerized transportation] to communicate better orders and meet with quality standards and 
commitment requirements. It is the best way to impact on clients and capture the whole margin". Second, the fact that market entry was overseen by a local partner alleviated the firm's lack of knowledge of the Spanish environment and, at the same time, provided it with immediate access to strategic resources so that it could compete with its global rivals. As the general manager mentioned, “... it was a simultaneous process which they repeated around the world, they were looking for local partners to create companies, joint ventures, around the world...". These comments provide evidence of an accelerated internationalization typical of EMNEs (see Luo and Tung 2007), often strengthened by the application of springboard strategies. Indeed, the introduction of the Chinese group in Spain was motivated in large measure by a springboard strategy, as "the country has an excellent image in Arab and Latin American countries [...] and also the connections of the Spanish ports with Latin America and the Middle East are strategic".

In contrast, the FDI history of Huayi Compressor in Europe began just a few years ago in 2013, when it took over a well-known Catalan company, Cubigel, in Sant Quirze del Vallès (Barcelona), which was experiencing financial problems. During almost three decades, Cubigel had been completely Catalan-owned, but in 1988 it joined the Swedish group, Electrolux Compressors. In the years that followed the firm changed hands several times: in 2003 it was acquired by the Italian group, ACC Appliances Components Companies; in 2009 it was bought by the North American private equity firm, AIAC; and, then, in 2013 Huayi Compressor gained control. The acquisition of Cubigel by the Sichuan Changhong Group, a leader in consumer electronic products and appliances, was the Chinese company's first incursion into manufacturing activity outside China. Huayi's activity in Spain is closely linked to its operations in China; however, there are differences in the application of the 
compressors manufactured ${ }^{6}$. Thus, while the subsidiary focuses its efforts on compressors for industrial and commercial refrigerators, the activity in China focuses on producing domestic compressors for home appliances.

Huayi's reasons for investing in Spain coincide in some respects with those of China Shipping. Thus, the firm was also seeking new market opportunities (Luo and Tung 2007), but here it not only targets the Spanish market but other adjacent markets too. Indeed, in 2014 the Chinese subsidiary exported $98 \%$ of its production to European countries as well as to Turkey, Israel, Russia and Latin American. In this respect, Barcelona acts as a springboard subsidiary of Huayi activities to Latin America. As the HR manager reported: "We have sales agents exclusively devoted to Latin American markets who sell the products of both businesses (commercial and domestic compressors). For us, it is easier to sell there since we share the same language and culture”.

However, unlike China Shipping, in this case access to technology acquired special relevance as a motivation for investing in Spain. Thus, the arrival of Huayi in Spain responded to the horizontal diversification of its business portfolio, which had previously been focused solely on domestic compressors, to include commercial/industrial compressors. Despite the shared technology of commercial and domestic compressors, the components have different specifications: first, technological characteristics, such as size, power and energy consumption, are more highly valued in industrial compressors than they are in domestic compressor; and, second, commercial elements, including, for example, the client profile, distribution methods and sales agents, differ considerably from domestic to industrial compressors. Consequently, new knowledge with regards to technology, operations, logistics,

\footnotetext{
${ }^{6}$ A compressor is a component of a vapor-compression refrigerating machine for engines, lowering the temperature of an enclosed space by removing heat from that space and transferring it elsewhere.
} 
suppliers and commercial activities was required. In addition, Barcelona boasts highly trained R\&D personnel while China operates some of the most advanced laboratories and infrastructure in the world; therefore, mutual knowledge transfer is extensive and frequent. Indeed, the HR manager reported, "Exchanges between Chinese and Spanish engineers are very common in Huayi”.

Institutional distance and liability of foreignness: isomorphic conflict

Once Chinese investors are physically present in a developed market, they encounter a considerable cultural distance due to markedly different institutional and social environments. Despite choosing external entry modes (as illustrated by China Shipping Group and Sichuan Changhong) to overcome the liability of foreignness and to access local institutional knowledge, EMNEs face a major cultural clash, which makes the integration of their subsidiaries a highly complex affair. Chinese culture contrasts with Spanish culture in many respects; according to the general manager of China Shipping: "We are not only talking about the language problem as a major constraint to communication; gestures, manners and nonverbal communication are also really difficult to understand ... everything is new for both parties". At the outset, in both EMNEs, the Chinese managers had a poor command of English and spoke no Spanish, making language skills the most obvious manifestation of the liability of foreignness suffered at the subsidiary level. In China Shipping, despite the broad internationalization of the company group, corporate communications are still sent to foreign subsidiaries in Chinese. The general manager explained: "Translating letters and internal communications all the time implies a loss of time when it would be easier if everything was written from the beginning directly in English". In Huayi, we observed that most Chinese expatriates consider the Chinese subsidiary a temporary destination, and so have little 
motivation to learn Spanish given that they have no intention of staying in the country long. As the HR manager pointed out: "We roughly understand each other in English because they hardly speak Spanish". A further obstacle for Chinese managers is attributable to problems of non-verbal communication. In fact, this mode of communication, which differs greatly in the two cultures, often hinders the exchange of views and, hence, the possibility of coming to a rapid understanding. In Huayi, the HR manager mentioned that: "The things that are very common for us are not so common for them; on the contrary, they do not assimilate certain modes of conduct that are quite distinct from their own forms of behaviour".

In addition to these communication barriers, other key factors highlight the distance between Chinese and Spanish cultures. One such factor is the great power distances that characterize Chinese MNEs, which means hierarchies can never be called into question (Hofstede 2001). Overall, the respect for the hierarchy and authority is an essential value in China Shipping Group. For instance, the general manager explained, "For Chinese managers it is difficult to understand that Spanish employees will not wear the same corporate T-shirt to work on casual Fridays, just because a top executive has come up with this idea". Likewise, in the Sichuan Changhong firm, the vertical hierarchy and the horizontal organizational structure are clearly defined and cannot be transgressed. In relation to the vertical hierarchy, the HR manager reported: "It is a question of authority, you can never challenge a decision that comes from above. If your boss orders you to do something, however trivial it might seem, he expects you to stop the job you have in hand immediately and to do it without discussion". These boundaries, moreover, are also very evident at the horizontal level. For instance, the scope of human resources management in European countries is much broader than in China (for a review see Cooke 2009). At Huayi, the HR staffs is actively involved in all functional 
areas of the subsidiary, in line with western leadership styles; however, this clashes with perceptions of the role of HR management in Sichuan Changhong where functions are carefully delimited in just one department. Thus, they are forever saying "you are Human Resources, do not get involved in anything else”.

Another important difference is the selflessness of Chinese workers. Unlike western employees, the Chinese have a high spirit of self-denial and are highly committed to their work. The general manager of China Shipping reported that: "In China there is no separation between life and work. For Chinese employees, work is more than work, it means their life and there are no borders between them. They are unable to say NO to work." In a similar vein, the Huayi HR manager explained that "Chinese managers do not understand why Spanish employees do not want to work at the weekend and why they do not consider working overtime as a great honour and as an opportunity to show the bosses how hard they work". In contrast to China, European societies place great value on their free time and, hence, strive to find a good work-life balance. Thus, these two different points of view are evidence of conflicting isomorphic pressures that are likely to result in misunderstandings.

Finally, the degree of centralization of decision-making at the multinational level is a further factor that reflects the marked power distances in Chinese culture (Hofstede 2001) and which gives rise to the evident subordination of the Chinese subsidiaries. It should be noted that this relationship is further strengthened in the case of SOEs. Consequently, our two Chinese subsidiaries have very little room for manoeuvre. In this respect, the general manager of China Shipping reported: "We receive very clear guidance regarding how to work, how to report and how to proceed. We only have some leeway in aspects associated with the links established with local authorities, human resources and national suppliers and sales issues". 
Likewise, the HR manager of Huayi noted: "We have zero autonomy. In the Chinese subsidiary everybody does what the general manager says, and the general manager only does what the parent company orders". Contrary to this approach, a European management style advocates the creation of more horizontal relations where the power distance between a group's companies is not so obvious. Here again, there is a risk of isomorphic conflict due to the differences between the two environments and the great cultural distance that separates them. All in all, these circumstances highlight the difficulties the Chinese expatriate managers face in adapting to the host-country. Although these managers are willing to adapt for the sake of the subsidiary's performance, their deep-rooted cultural values prevent them from full integration into the new environment. In the words of Huayi's HR manager "Although Chinese managers are open to adaptation, their habits and values are so different and well established that when they come back from China, after a long time, you have to remind them and explain it to them again and again". Once again, these differences between the two cultures accentuate the isomorphic conflict which has to be tackled in order to facilitate understanding.

\section{Mitigating isomorphic conflict}

The differences characterizing the two institutional environments, that is, the specific requirements for achieving both external and internal legitimacy, make cultural integration a great challenge. In their awareness of this, parent companies typically appoint mixed Chinese and Spanish subsidiary boards of directors. For example, in the case of Huayi, while the board is predominantly Chinese, the managers of the $R \& D$ and sales departments are Spanish, while in the case of China Shipping, although the board of directors is made up primarily of Spanish managers, the Managing Director and Financial Controller are Chinese. Similar evidence has 
been reported by Si and Liefner (2014) and Klossek et al. (2012) in Germany, who likewise report the existence of mixed teams.

In China Shipping, the Spanish managers play a key role as enablers of the adaptation of Chinese expatriates, acting as a bridge between the local way of behaving (embedded in relationships with local agents) and the parent office's values (embodied in the Chinese expatriates). In this regard, the general manager explained: "We have to remind Chinese managers that they have no choice other than to adapt to certain cultural or legal norms if they want to operate with success in Spain”. In order to ensure adaptation, local subsidiary managers have to make great efforts to understand the will and actions of Chinese expatriates and, at the same time, teach them which procedures are welcome in the new environment and which are not. Moreover, local subsidiary managers also have the responsibility to learn from the Chinese culture and its values and to transfer an awareness of them to the local employees. According to the manager of China Shipping Spain: "We try to transfer Chinese customs and modes of conduct to our local employees. We celebrate the Chinese New Year, we hold dinners together [...] We try to transfer all this information and at the same time we also try to communicate to them our habits, customs and Spanish ways of behaving [...] all this is very different for them".

A useful way to approach Chinese cultural values is via the adoption of guanxi - the ancient system of personal relationships and social connections based on mutual interest and benefit (Hwang 1987; Kipnis 1997) and one of the more deep-seated business practices in China - by local subsidiary managers. In the cases analysed, local subsidiary managers are encouraged to promote guanxi in their local relations so as to give a Chinese meaning to their actions, to increase their legitimacy in the eyes of expatriate managers and to win the favour of the 
parent company. However, to avoid becoming overly detached from their Spanish environment, they must at the same time adapt guanxi, as far as it is possible, to the local requirements of business relationships. We found that both Chinese subsidiaries seek to implement the three components of guanxi identified above (i.e., renqing, xinren and ganqing) in their attempts to respond to different institutional forces and, in short, as a vehicle to resolve the isomorphic conflict.

For Chinese managers, reciprocity and empathy are essential for the success of their commercial relationships (Hwang 1987), which are based on the continuous exchange of favours (renqing). Although it would seem that these principles form part of the universal language of business, in China personalized networks of influence, largely based on understanding and long-lasting linkages, constitute an especially strong guiding principle. As explained by the local subsidiary managers interviewed here, the subsidiaries have internalized these ways of proceeding and adhere to these rules of favours. In the case of China Shipping, "If you have a good commercial relationship it is normal to do favours in a business context; however, the Chinese have a longer conception of time due to the social beliefs of Confucianism. You are under no obligation to return the favour immediately, on the contrary, years may pass until you pay back the favour". According to Huayi's manager, "In business, you have to take care of your commercial networks and knit good relationships with customers. That sometimes implies doing favours. Nevertheless, Chinese businessmen never forget. If somebody owes you a favour, even if it was a long time ago, you expect it to be returned”.

As a matter of fact, in the Chinese culture, the exchange of favours often transcends business dealings into personal relationships. Here, the relationships forged between Chinese expatriate 
and Spanish managers acquire particular prominence. For example, we found evidence in both companies of local subsidiary managers solving the day-to-day problems of their Chinese counterparts. "They usually ask you if you can introduce them to a person of interest to them or help them with a personal matter ... anyway, Chinese managers tend to rely on us", explained the general manager of China Shipping. In this way, over time, by means of repeated favours, a useful channel of communication is opened up between the Spanish managers and the Chinese expatriates. In other words, Spanish managers have learnt to successfully apply the guanxi code of conduct in their dealings with Chinese expatriates and have, thus, built strong relationships of trust.

The essence of any business relationship for a Chinese manager is continuous and repeated evidence of trust. Only over time and with the achievement of good outcomes is it possible to gain credibility (xinyong) and, so, build the bases of mutual trust and confidence (xinren) (Yen et al. 2011). In this respect, the general manager of China Shipping claims: "Trust is a basic aspect of successful professional relationships, but for the Chinese it is much greater than this. It is very difficult to enter in their circle of trust; you have to gain it day by day, gradually, by demonstrating good results. In that sense, the Spanish subsidiary has won considerable credibility within the Chinese MNC, obtaining better quality indicators than those obtained by other European subsidiaries". And he adds: "Once you have eventually won their confidence it becomes a much deeper friendship than others".

Therefore, it is not until Spanish managers manage to win the confidence of Chinese expatriates that they can enter into their closed circle and develop friendly ties, thus increasing understanding between Chinese expatriates and local employees and fostering cultural integration. To this end, local managers also take great care in getting Chinese managers 
emotionally involved (ganqing) with the Chinese subsidiary by promoting regular social interactions. For instance, the general manager of China Shipping reported, "In order to work properly with Chinese managers you have to respect and show interest in their culture and life style. Going out for dinners, tasting Chinese food or going singing are things that you must do to be kind and make things work". In a similar vein, Huayi's HR manager noted: "Huayi shows great concern for its employees, giving them many gifts on different occasions (fruit, wine, 'jamón serrano', chocolates, etc.). The intention is to get them involved and to be grateful to the firm". He added, "Huge meals, toasts of friendship and football matches between the Spanish and Chinese take place often. Since the Chinese managers are a long way from their country and families, they feel the need to make friends here". This common ground serves as a 'social glue' for the sharing of experiences and for learning more about each other's culture, prompting mutual adaptation and resolving isomorphic conflicts (Forsgren 2013).

Thus, thanks to the efforts of the Spanish managers and their attempts at promoting guanxi practices a mutual adaptation and rapprochement of cultures that facilitate understanding can be achieved. Indeed, by balancing these two forces, Chinese subsidiaries attain both internal and external legitimacy. In this context, and given the great cultural distance between China and Spain, Spanish managers have to be very careful to manage in accordance with the parent company's culture (internal legitimacy) without neglecting local requirements (external legitimacy) if they want to guarantee the success of the investment in the host country. In short, our results indicate that the greater the institutional distance between the MNE's home country and the subsidiary's host country, the more the subsidiary will seek to adapt the 
parent office's practices to the host country environment in an attempt at resolving the isomorphic conflict.

\section{Conclusions and future research}

Our findings show that, in line with the growth in global FDI from emerging countries, Chinese direct investment in Spain has experienced an upward trend in the last decade, above all during the period of international financial crisis. The phenomenon remains new and is relatively small compared to the investment of multinationals based in developed countries; however, there is evidence that it is set to become more and more important in the future, despite the forecasts of a slowdown in the China economy.

Much of the success of Chinese FDI in Southern Europe is attributable to the integration of cultures in contexts where the distance between the respective institutional environments is great (Kostova and Zaheer 1999) and the way in which they go about resolving their isomorphic conflicts (Forsgren 2013). In this respect, previous research has highlighted the significance of the Chinese tradition of guanxi and its widespread use in Chinese society (see, for example, Hwang 1987; Yang 1994; Lee and Dawes 2005; Huang et al. 2010). However, to date little has been written about how Chinese firms interact with the cultures of their hostenvironments and how they deal with guanxi in foreign countries. In that sense, this article goes some way to filling this gap through its analysis of two Chinese subsidiaries located in Spain.

Our results show that guanxi is in widespread use beyond the borders of China too. Although Chinese expatriates are fully aware of their liability of foreignness in developed markets precisely because of the marked cognitive-cultural distance between both environments, they are unable to discard guanxi practices as they are deeply-rooted in the Chinese way of doing 
business and, moreover, they do not wish to jeopardise headquarters' confidence in them as most hope to take up a position there on their return home.

This being the case, foreign subsidiaries adopt and adapt guanxi practices, insofar as this is permitted by the institutional environment of the host country. Local subsidiary managers play a role in converting the guanxi practices of Chinese expatriates in legitimate actions in relation to the rest of the local employees and local actors, including suppliers, customers and the public administration. To do so, Spanish managers have to involve themselves in guanxi practices in order to win the confidence of Chinese expatriates. It should be noted that without the rapprochement of cultures that facilitates mutual understanding, the communication channel between the two parties would remain quite ineffectual for transferring knowledge and resolving the isomorphic conflict (Forsgren 2013).

The adaptation of guanxi practices to the local cultural environment can act as a 'social glue', allowing the subsidiary to align itself with the culture of the parent organization at the same time as it embeds itself in the host environment. Indeed, the subsidiary has to strive to achieve this balance between home- and host-country institutional contexts by adapting guanxi practices to local requirements. Within this process of isomorphic conflict resolution, local subsidiary managers take on a key role in the success of Chinese FDI in developed countries. They act as a bridge, reducing the cultural-cognitive distance by transferring mutual knowledge between the host's institutional environment and that of the corporation. Here, we have highlighted the fact that adapting guanxi practices to the context of a developed country, such as Spain, is essential in enabling Chinese subsidiaries to balance their need to manage globally (in accordance with their parent organization's culture and, hence, to ensure their internal legitimacy) with the need to manage locally (in accordance with the social beliefs and 
values of the host country and, hence, to ensure their external legitimacy) (see Figure 1). In short, this study provides additional insights to the guanxi literature by exploring how Chinese MNEs, and in particular their western subsidiaries, adjust their guanxi practices outside China in order to resolve the isomorphic conflict.

Figure 1. Conceptual framework

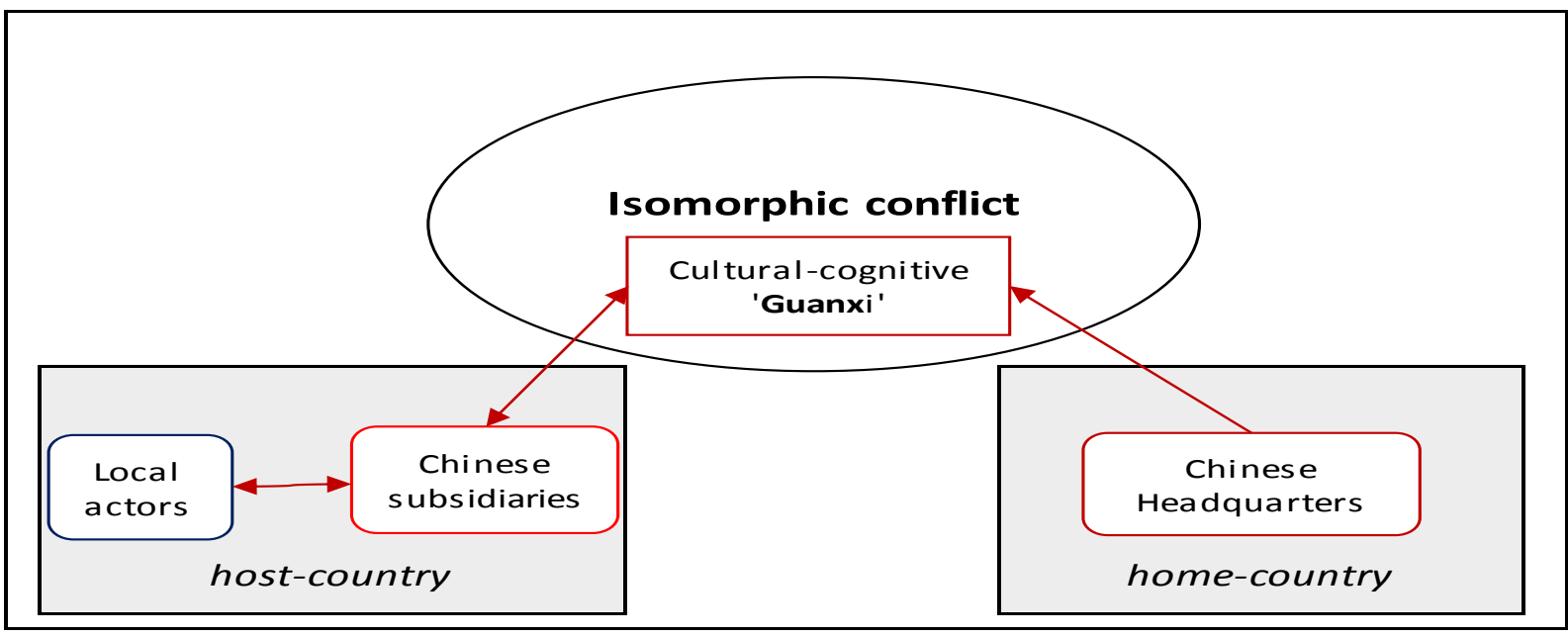

Finally, we need to acknowledge certain limitations of the present study, which in all circumstances provide clear indications for future research. First, in our analysis we have only examined the point of view of local managers of Chinese subsidiaries. The present results would undoubtedly be greatly enriched by integrating the opinions of Chinese expatriates as well as those of members sitting on the boards of directors back at the Chinese headquarters. These additional perspectives would provide us with a more complete vision of cultural integration. Second, as in other studies based on a sample of just two firms, our results cannot be generalized. In that sense, a broader sampling of Chinese subsidiaries in other countries of Southern Europe is needed. Finally, we have opted to focus solely on Chinese FDI; however, extending the research to include other emerging countries would enable us to compare the EMNEs from different environments and report more compelling findings about the 
legitimacy-seeking behaviour of EMNEs in developed markets. Indeed, a quantitative study would further mitigate this limitation by enabling us to test hypotheses related to the resolving of isomorphic conflicts via cultural adaptation and the achievement of internal and external legitimacy.

\section{References}

Aminian, Nathalie, Fung, K. C., and Lin Chelsea. 2008. "Outward Direct Investment from East Asia: Experiences of Hong Kong and Taiwan." In New Dimension of Economic Globalization: Surge of Outward Foreign Direct Investment from Asia, edited by Ramkishen S. Rajan, Rajiv Kumar, and Nicola Virgill. World Scientific Publication.

Bitektine, Alex. 2011. "Toward a theory of social judgements of organizations: the case of legitimacy, reputation, and status." Academy of Management Review 36:151-179.

Boyacigiller, Nayike, Richard Goodman, and Margaret Phillips. 2004. Crossing Cultures: Insights from Master Teachers. London: Routledge.

Buckley, Peter J., and Mark Casson. 1976. The Future of Multinational Enterprise. New York: Holmes and Meier Publishers.

Buckley, Peter J., Clegg, Jeremy, Cross, Adam. R., Liu, Xin, Voss, Hinrich, and Zheng, Ping. 2007. "The determinants of Chinese outward foreign direct investment." Journal of International Business Studies 38:499-518.

Chang, Yi-Ying, Gong, Yaping, and Mike W. Peng. 2012. "Expatriate knowledge transfer, subsidiary absorptive capacity, and subsidiary performance." Academy of Management Journal 55: 927948.

Chen, Shih. 2008. "The motives for international acquisitions: Capability procurements, strategic considerations, and the role of ownership structures." Journal of International Business Studies 39: 454-471.

Chen, Xiao-Ping, and Chao C. Chen. 2004. "On the intricacies of the Chinese Guanxi: A process model of Guanxi development." Asia Pacific Journal of Management 21: 305-324.

Chen, Homin, Hsu, Chia, W., and Caskey D'Arcy. 2013. "Internationalization of Taiwanese manufacturing firms: The evolution of subsidiary mandates and capabilities." Asian Business and Management 12: 37-60. 
Chiao, Yu-Ching, and Kung-Pao Ying. 2013. "Network effect and subsidiary autonomy in multinational corporations: An investigation of Taiwanese subsidiaries." International Business Review 22: 652-662.

Child, John, and Suzana B. Rodrigues. 2005. "The internationalization of Chinese firms: A case for theoretical extension." Management and Organization Review 1: 381-410.

Cooke, Fang L. 2009. "A decade of transformation of HRM in China: A review of literature and suggestions for future studies." Asia Pacific Journal of Human Resources 47: 6-40.

Cuervo-Cazurra, Álvaro. 2007. "Sequence of value-added activities in the internationalization of developing country MNEs.” Journal of International Management 13: 258-277.

Cui, Lin, and Jiang Fuming. 2010. "Behind ownership decision of Chinese outward FDI: Resources and institutions." Asia Pacific Journal of Management 27: 751-774.

Deng, Ping. 2009. "Why do Chinese firms tend to acquire strategic assets in international expansion?" Journal of World Business 44: 74-84.

DiMaggio, Paul J., and Walter W. Powell. 1983. "The iron cage revisited: institutional isomorphism and collective rationality in organizational fields." American Sociological Review 48:147-160.

Dunning, John. 1979. "Explaining Changing Patterns of International Production: In Defence of an Eclectic Theory." Oxford Bulletin of Economics and Statistics 41: 269-295.

Eisenhardt, Kathleen M. 1989. "Building theories from case study research." The Academy of Management Review 14:532-550.

ESADE. 2014. "Chinese investment in Europe 2014". Barcelona: ESADE China Europe Club.

EUROSTAT. 2011. "Sectorial classification". Accessed October 13, 2015. http://ec.europa.eu/eurostat/cache/metadata/Annexes/htec_esms_an3.pdf.

Forsgren, Mats. 2013. Theories of the multinational firm: A multidimensional creature in the global economy. UK: Edward Elgar Publishing.

Gaffney, Nolan, Cooper, Danielle, Kedia, Ben, and Jack Clampit. 2014. "Institutional transition, global mindset, and EMNE internationalization.” European Management Journal 32: 383-391.

Gaffney, Nolan, Kedia, Ben, and Jack Clampit. 2013. "A resource dependence perspective on EMNE FDI strategy." International Business Review 6: 1092-1100.

Gammeltoft, Peter, Barnard, Helena, and Anoop Madhok. 2010. "Emerging Multinationals, Emerging Theory: Macro and Micro-Level Perspectives." Journal of International Management 16: 95101.

Guillen, Mauro. F., and Esteban García-Canal. 2009. "The American model of the multinational firm and the 'new' multinationals from emerging economies." Academy of Management Perspectives 23: $23-35$. 
Gummesson, Evert. 2006. "Qualitative research in management: addressing complexity, context and persona." Management Decision 44: 167-179.

Hitt, Michael A., Hoskisson, Robert E., and Kim Hicheon. 1997. "International Diversification and Firm Performance in Product Diversified Firms.” Academy of Management Journal 40:767-798.

Hofstede, Geert H. 2001. "Cultures consequences: Comparing values, behaviours, institutions and organizations across nations." (2nd ed.). Thousand Oaks, CA: Sage Publications.

Hong, Junjie, Wang, Chengqi, and Mario Kafouros. 2015. "The Role of the State in Explaining the Internationalization of Emerging Market Enterprises.” British Journal of Management 26:45-62.

Huang, Lan-Ying., Baek, H. Young, and S.Min. 2010. "Key drivers of guanxi in China among Taiwanese small to medium-sized firms." International Business Research 3: 136-146.

Hymer, Stephen H. 1960. "The international operations of national firms, a study of direct foreign investment." Dissertation, Massachusetts Institute of Technology.

Hwang, Kwang. 1987. "Face and favor: The Chinese power game." American Journal of Sociology 92: 944-974.

International Monetary Fund-IMF. 2016. "World Economic Outlook 2016: Too slow for too long." World Economic and Financial Surveys, April 2016.

Khanna, Tarun, and Palepu Krishna. 2006. "Emerging giants: building world-class companies in developing countries." Harvard Business Review 84: 60-71.

Kipnis, Andrew B. 1997. "Producing guanxi”. Durham NC:Duke University Press.

Klossek, Andreas, Linke, Bernd M., and Michael Nippa. 2012. "Chinese enterprises in Germany: Establishment modes and strategies to mitigate the liability of foreignness." Journal of World Business 47: 35-44.

Kolstad, Ivar, and ArneWiig. 2012. "What determines Chinese outward FDI?" Journal of World Business 47: 26-34.

Kostova, Tatiana, and Srilata Zaheer. 1999. "Organizational legitimacy under conditions of complexity: The case of the multinational enterprise." Academy of Management Review 24: 6481.

Kostova, Tatiana, Roth, Kendall, and Tina Dacin. 2008. "Institutional theory in the study of MNCs: a critique and new directions." Academy of Management Review 33: 994-1006.

Lee, Don Y., and Philip L. Dawes. 2005. "Guanxi, trust, and long-term orientation in Chinese business markets." Journal of International Marketing 13: 28-56.

Luo, Yadong, and Rosalie L. Tung. 2007. "International expansion of emerging market enterprises: A springboard perspective.” Journal of International Business Studies 38: 481-498. 
Luo, Yadong, and Huaichuan Rui. 2009. "An Ambidexterity Perspective toward multinational enterprises from emerging economies." Academy of Management Perspectives 23: 49-70.

Luo, Yadong, Xue, Qiuzhi, and Han Binjie. (2010). "How emerging market governments promote outward FDI: Experience from China." Journal of World Business 45: 68-79.

Mathews, John. A. 2002. "Competitive advantages of the latecomer firm: a resource-based account of industrial catch-up strategies." Asia Pacific Journal of Management 19: 467-488.

Mathews, John. A. 2006. "Dragon multinationals: New players in 21 st century globalization." Asia Pacific Journal of Management 23: 5-27.

MOFCOM. Various years Statistical Bulletin of China's Outward Foreign Direct Investment. Beijing: MOFCOM. Accessed March 15, 2016.

http://english.mofcom.gov.cn/article/statistic/foreigninvestment

Morck, Randall, Yeung, Bernard, and Minyuan Zhao. 2008. "Perspectives on China's outward foreign direct investment.” Journal of International Business Studies 39: 337-350.

Nicholson, Rekha R., and Julie Salaber. 2013. "The motives and performance of cross-border acquirers from EE: Comparison between Chinese and Indian firms." International Business Review 22: 963-980.

Nicolas, Françoise. 2014. "China's direct investment in the European Union: challenges and policy responses." China Economic Journal 7: 103-125.

North, Douglass. C. 1990. "Institutions, Institutional Change and Economic Performance." Cambridge: Cambridge University Press.

Peng, Mike, W. Wang, Denis. Y. L., and Yi Jiang. 2008. "An institution based view of international business strategy: a focus on emerging economies." Journal of International Business Studies 39: 920-36.

Ramamurti, Ravi. 2009. "What we have learned about emerging-market MNEs?" In Emerging Multinationals in Emerging Markets, edited by R. Ramamurti, and J. V. Singh, 399-424. New York: Cambridge University Press.

Ramasamy, Bala, Yeung, Matthew, and Sylvie Laforet. 2012. "China's outward foreign direct investment: location choice and firm ownership." Journal of World Business 47: 17-25.

Rhodium. 2015. "Chinese investment into Europe. Reaching new heights." Rhodium Group/Baker \& McKenzie. Accessed 15 March 2016. http://www.bakermckenzie.com.

Rui, Huaichuan, and George S. Yip. 2008. "Foreign acquisitions by Chinese firms: a strategic intent perspective.” Journal of World Business 43: 213-226.

Schüler-Zou, Yun, and Margot Schüller. 2013. “An empirical study of Chinese subsidiaries' decisionmaking autonomy in Germany." Asian Business \& Management 12: 321-350. 
Scott, W. Richard. 1995. Institutions and organizations: ideas and interests. USA: Sage.

Si, Yuefang, and Ingo Liefner. 2014. "Cognitive distance and obstacles to subsidiary business success: the experience of Chinese companies in Germany." Tijdschrift voor Economische en Sociale Geografie 105: 285-300.

United Nations Conference on Trade and Development-UNCTAD. 2015. World Investment Report: Global Investment trend monitor. New York and Geneva: United Nations.

Wang, Cheng L. 2007. "Guanxi vs. relationship marketing, exploring underlying differences." Industrial Marketing Management 36: 81-86.

Wang, Cheng L., Siu, Noel Y. M., and Bradley R. Barnes. 2008. "The significance of trust and renqing in the long-term orientation of Chinese business-to-business relationships." Industrial Marketing Management 37: 819-824.

Wang, Chengqi L., Hong, Junjie, Kafouros, Mario, and Mike Wright. 2012. "Exploring the role of government involvement in outward direct investment from emerging economies". Journal of International Business Studies 43: 655-676.

Wei, Tian, Clegg, Jeremy, and Lei Ma. 2015. "The conscious and unconscious facilitating role of the Chinese government in shaping the internationalization of Chinese MNCs." International Business Review 24: 331-343.

Wong, Loong. 2012. “'Liability of foreignness': Chinese investment in Australia.” Transnational Corporations Review 4: 46-75.

Yang, Mayfair. M. 1994. Gifts, favors, and banquets: The art of social relationships in China. Ithaca, NY: Cornell University Press.

Yen, Dorothy. A., Barnes, Bradley. R., and Cheng L. Wang. 2011. "The measurement of Guanxi: Introducing the GRX scale." Industrial Marketing Management 40: 97-108.

Zaheer, Srilata. 1995. "Overcoming the Liability of Foreignness." The Academy of Management Journal 38: 341-63.

Zaheer, Srilata, and Elaine Mosakowski. 1997. "The Dynamics of the Liability of Foreignness: A Global Study of Survival in Financial Services.” Strategic Management Journal 19: 439-63.

This is an Open Access article distributed under the terms of the Creative Commons Attribution-Non-Commercial-No Derivatives License (http://creativecommons.org/licenses/by-nc-nd/4.0/), which permits non-comercial re-use and distribution, provided the original work is properly cited, and is not altered or transformed in any way. 